\title{
Strategic planning for waste management: A case study of Shiraz waste management
}

\author{
Ali Zangi Abadi ${ }^{\mathbf{a}^{*}}$ and Dariush Ahmadi ${ }^{\mathbf{b}}$
}

${ }^{a}$ Ph.D,Geography and city planning associate professor, university of Isfahan, Isfahan, Iran ${ }^{b}$ Dariush Ahmadi,Geography and city planning Ph.D student, university of Isfahan, Isfahan, Iran

\begin{tabular}{l}
\hline A R T I C L E I N F O \\
\hline Article history: \\
Received March 2, 2012 \\
Received in Revised form \\
May, 1, 2012 \\
Accepted 2 May 2012 \\
Available online \\
May 12 2012 \\
\hline Keywords: \\
Garbage management strategy \\
QSPM \\
SWOT \\
Strategic policy
\end{tabular}
A B S T R A C T

\begin{abstract}
These days, there are several reports indicating on reduction on renewable resources. On the other hand, there is an increase on the population, which increases production of garbage in the world. With limitation on governmental budget, there is growing concern on having efficient strategic planning for waste management. The proposed study of this paper performs a SWOT analysis to find all strength, weakness, opportunities as well as possible threats associated with waste management organization located in city of Shiraz, located in south west of Iran. Based on the results, appropriated locating strategies for burying garbage, training and increasing awareness regarding production and collection, attracting foreign investment in the field of recycling garbage, reconsidering environmental rules and burying garbage and its separation standards are the most important strategies.
\end{abstract}

\section{Introduction}

Waste management is getting more and more important among different people and societies specially those who live in populated cities (Johnson et al., 1989; David, 1998). Every day, a significant amount of waste and disposals are generated by civilians and they must be managed, properly to keep the environment safe and healthy (Williams, 1998; Tammemagi, 1999). Waste management can become easy where appropriate sites become available and sanitary landfills normally provide the most efficient tool for disposal of non-recyclable refuse. Nevertheless, it is getting increasingly difficult to find sites, which offer enough capacity, accessibility, and environmental conditions (Scarlett, 2007). Landfills always play important role in solid-waste management and it is almost impossible to recycle all components of solid waste, and there are always some residues from incineration and other treatment processes, which eventually need disposal underground and landfills can virtually improve poor-quality land and there are cases where some of these landfills could be converted into recreational parks and many other related benefits are still under investigation.

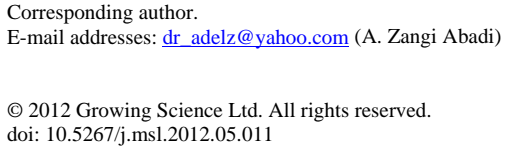


During the past two decades, there have been tremendous efforts on using recent advances on technology innovations to better manage landfills (Clarke, 1998). Engelen et al. (1997) explained integrating constrained cellular automata models, GIS and decision support tools for urban planning and policy-making.

Eastman et al. (1995) implemented multi-criteria/multi-objective decision making techniques along with an exploration of new set of decision support tools for handling the large amount of data required of raster GIS. They used their proposed method to illustrate these tools as developed for the waste management analysis. Chang et al. (1996) presented sustainable waste management strategies in which the decision makers may put forward their insights on material recycling and the assimilative capacity of the environment for two major factors including air pollution control and leachate effect. Change et al. (1996) proposed a new mixed integer programming model with the framework of dynamic optimization to provide optimal waste management control.

Some of these investigations are focused on strategic planning such as investigating on strengths, weaknesses, opportunities and threats normally summarized as SWOT. According to Halla (2007) preparation and implementation of urban general and detailed planning schemes have motivated most practitioners of urban and regional development planning and management worldwide. Since 1990s, the professional practice has been directed by the political-economy or urban management paradigm, which includes participatory, transparency, flexibility and being strategic. Whereas urban design needs to be implemented in preparation and implementation of urban detailed planning plans at subcity level and urban management has continued to replace the procedural or master planning approach for citywide general planning schemes. Strengths, weaknesses, opportunities and threats (SWOT) surrounding the procedural or master-planning approach have been widely but negatively analyzed in the existing literature.

Kurttila et al. (2000) proposed a hybrid technique for improving the usability of SWOT using analytic hierarchy process (AHP), where its eigenvalue computation framework were integrated with SWOT analysis. AHP's connection to SWOT helps determine priorities for SWOT analysis. They applied the hybrid method to make the quantitative information basis of strategic planning processes more efficient. They used their hybrid method for a Finnish case study on forest certification and the results were investigated by utilizing the quantitative information. They reported that certification could be a potential strategic alternative for the case study farm and the AHP comparisons were quite useful, because they asked the decision maker to think over the weights of the factors and to analyze the situation more carefully. Halla (2007) used SWOT analysis based on the urban management technique using the case of Dar es Salaam City in Tanzania. Halla investigated many related materials and adopted in capturing and analyzing the necessary data. Halls's findings helped make a conclusion that the urban management approach was stronger than the procedural or master-planning approach in planning and managing cities, generally, and planning and managing Dare s Salaam City.

Stewart et al. (2002) discussed the necessity for efficient implementation of information technology (IT) and information systems (IS) in different empirical and prescriptive research studies such as construction industry, which has been slow to handle and utilize new technologies with negative consequences on creativity and innovation. They presented a strategic implementation model for IT/IS projects in construction and built a comprehensive well-documented predictors for efficient IT/IS implementation. They used a case study with a large multi-national construction organisation to show the strategic implementation of a project management IS implemented for the construction of a mobile phone telecommunications network in the South East of Queensland, Australia. Kumar et al. (2004) explained the issue of solid waste (SW) in developing countries like India, where urban SW generation increases enormously and most of the SWs are disposed through land filling in low-lying areas, which generates large amount of biogas. Methane, the major constituent gas is blamed as one of the most important in global warming for its green house gas (GHG) impact. There is no doubt that 
we need to study different factors of SW on global GHG effect. Kumar et al. (2004) estimated methane emission for a particular landfill site, and proposed a new methodology. Their results indicated that total methane generation was the same for both theoretical methodologies, but their proposed method seemed to perform better since it provided a time-dependent emission profile, which reflected the true pattern of the degradation process.

\section{The proposed method}

Knowing capabilities obstructions, opportunities and threats is among some basic points in learning and managing qualitative phenomena. In this method, weak and strong points are analyzed as internal factors, threats and opportunities are analyzed as external factors, and in fact, the prevailing logic is that effective strategy should maximize the strengths and opportunities and should minimize weak points and threats. To determine the before-mentioned point in the area under interest we acted in this way that these points are presented in the form of SWOT tables and containing 4 points each. In fact the analysis based on SWOT is to systematically identify the factors in which the strategy should be best compatible. In the next step using quantifying techniques of qualitative concepts, we realize the priorities and to evaluate the external and internal strategic factors (IFE) and external strategic factors (EFE), some matrix based SWOT is used. In order to verify the strategic factors of Shiraz garbage management we acted based on the following algorithm.

\subsection{The proposed SWOT}

The following four-step procedure shows details of our proposed model.

The first step: with regard to various problems and dilemmas, the strength and weakness points, opportunity and threat in different sectors of garbage production, collection, transportation, sepulture and recycling are determined.

The second step: According to the scores given the related tables to IFE and EFF are provided and then the score of each item is given using normalizing method.

The third step: Using QSPM method, the quantitative strategic matrix is provided so that we can determine different and effective strategies in Shiraz garbage management.

The fourth step: In this step; after verifying capacities and capabilities analysis system based on SWOT, we categorize them and the ones with the highest average/mean score called critical criterion is selected as intervening strategy and all the others will be prioritized.

\section{Case study}

The proposed study is investigated for one of well known cities in Iran called Shiraz located in northwest of the country (See Fig. 1).



Fig. 1. The city of Shiraz 
According to official survey accomplished by statistical organization of Iran in 2009, Shiraz had a population of approximately1455073 people and the population increases steadily.

\section{The implementation}

We first discuss the first step of the proposed SWOT method and the results are given in Table 1.

Table 1

Strong points weak points, garbage production opportunities and threat

\begin{tabular}{|c|c|c|c|c|}
\hline $\begin{array}{l}\text { Internal } \\
\text { factors }\end{array}$ & $\begin{array}{l}\text { Strong points } \\
\text { S }\end{array}$ & Household led man awareness & $\begin{array}{l}\text { Weak } \\
\text { point } \\
\text { W }\end{array}$ & $\begin{array}{l}\text { Increasing the un-renewable garbage production } \\
\text { amount } \\
\text { Providing increasing the amount of garbage at the first } \\
\text { Not using the unattractive materials by environment }\end{array}$ \\
\hline $\begin{array}{l}\text { External } \\
\text { factors }\end{array}$ & $\begin{array}{l}\text { Opportunities } \\
\text { O }\end{array}$ & $\begin{array}{l}\text { Existing environment standards about } \\
\text { garbage production } \\
\text { Providing culture by city planning } \\
\text { Regarding a time table of garbage egress }\end{array}$ & $\begin{array}{l}\text { Threats } \\
\mathrm{T}\end{array}$ & $\begin{array}{l}\text { Production dangerous garbage(hospital and electronic) } \\
\text { increasing } \\
\text { Consumerism increasing }\end{array}$ \\
\hline $\begin{array}{l}\text { Internal } \\
\text { factors }\end{array}$ & $\begin{array}{l}\text { Strong points } \\
\text { S }\end{array}$ & $\begin{array}{l}\text { Existing the modern system at garbage } \\
\text { transportation } \\
\text { Having ceiling automobile garbage } \\
\text { transportation part }\end{array}$ & $\begin{array}{l}\text { Weak } \\
\text { point } \\
\text { W }\end{array}$ & $\begin{array}{l}\text { Increasing city traffic } \\
\text { Not regarding a garbage transportation time table }\end{array}$ \\
\hline $\begin{array}{l}\text { External } \\
\text { factors }\end{array}$ & $\begin{array}{l}\text { Opportunities } \\
\text { O }\end{array}$ & $\begin{array}{l}\text { Existing laws instruction and driving } \\
\text { transportation Possibility of garbage lorry } \\
\text { the last time of night }\end{array}$ & $\begin{array}{l}\text { Threats } \\
\mathrm{T}\end{array}$ & $\begin{array}{l}\text { Collection and transportation problems at raining time } \\
\text { with regard to leaking faucet from garbage } \\
\text { Intercity accident possibility }\end{array}$ \\
\hline $\begin{array}{l}\text { Internal } \\
\text { factors }\end{array}$ & $\begin{array}{l}\text { Strong points } \\
\text { S }\end{array}$ & ---- & $\begin{array}{l}\text { Weak } \\
\text { point } \\
\text { W }\end{array}$ & $\begin{array}{l}\text { Incorrect site selection for garbage sepulture place } \\
\text { Residue unsanitary sepulture } \\
\text { Garbage sepulture without considering the type of } \\
\text { them }\end{array}$ \\
\hline $\begin{array}{l}\text { External } \\
\text { factors }\end{array}$ & $\begin{array}{l}\text { Opportunities } \\
\text { O }\end{array}$ & $\begin{array}{l}\text { Existing the laws of environment about } \\
\text { garbage sepulture method } \\
\text { Preparing sepulture management executive } \\
\text { schedule } \\
\text { Partnership possibility of private part at } \\
\text { garbage sepulture }\end{array}$ & $\begin{array}{l}\text { Threats } \\
\mathrm{T}\end{array}$ & $\begin{array}{l}\text { Being polluted natural sources especially earth and } \\
\text { underground water } \\
\text { Stability of some of garbage at environment and not } \\
\text { attracting them by environment } \\
\text { Extending and speedup contagious sicknesses }\end{array}$ \\
\hline $\begin{array}{l}\text { Internal } \\
\text { factors }\end{array}$ & $\begin{array}{l}\text { Strong points } \\
\text { S }\end{array}$ & $\begin{array}{l}\text { Thrift at primary materials } \\
\text { Decreasing a dimension and weight of } \\
\text { garbage } \\
\text { Biotechnology development }\end{array}$ & $\begin{array}{l}\text { Weak } \\
\text { point } \\
\text { W }\end{array}$ & $\begin{array}{l}\text { Not notifying about recycling } \\
\text { Opulence ability lack for recycling and separating } \\
\text { possibility } \\
\text { Low benefit of recycling garbage for garbage producer }\end{array}$ \\
\hline $\begin{array}{l}\text { External } \\
\text { factors }\end{array}$ & $\begin{array}{l}\text { Opportunities } \\
\text { O }\end{array}$ & $\begin{array}{l}\text { Being attractive for private part investment } \\
\text { external investment attracting possibility } \\
\text { about recycling garbage } \\
\text { Existing modern technology to recycle } \\
\text { garbage }\end{array}$ & $\begin{array}{l}\text { Threats } \\
\mathrm{T}\end{array}$ & $\begin{array}{l}\text { People diffidence to recycling goods } \\
\text { Low standards about goods production from recycling } \\
\text { Lack of workforce skillful } \\
\text { Recycling technology weakness }\end{array}$ \\
\hline
\end{tabular}

The second step: In this step, using the comments and scores of the statistical population external and internal factor evaluation matrixes are provided. IEF is a technique to examine internal factors and it evaluates the strength and weakness points of the units of interested topic. External Factor Evaluation matrix (EFE) is also a tool, which helps analyze the responses to opportunities and threats outside the examined subject or topic. After an assessment, we can state that the highest score in internal factor matrix is 19 and external factor is 20 . Then we assign an appropriate normalized weight coefficient to every factor between zero (not important) and 1 (very important). The given coefficient to every interested factor is considered as strong or weak point inside the organization.

We need to give the highest coefficient to the factor, which has the highest performance effect in organization. Then the current condition of every factor is given as score between 1 and 4 [1:weak 2:average 3:more than average 4: very good] which is called current condition score. In this step the sum of weight scores are estimated. If the final IEF score is below 3 this means the proposed points in garbage management regarding internal factors is a critical issue and needs to be investigated for possible remedy. In addition, if the final EFE score is below 3, this indicates that garbage management could not act well regarding using the opportunities and facing threats. Table 2 shows internal factors matrix and Table 3 shows external factors matrix. 
Table 2

Internal factors matrix (IFE) (Weakness)

\begin{tabular}{lllll}
\hline strength & Current point & point & Normal & end Point \\
\hline Household led man awareness & 4 & 19 & 0.05 & 0.2 \\
Training collection part egression & 4 & 19 & 0.03 & 0.12 \\
Advertising about a time of garbage collection & 2 & 17 & 0.04 & 0.08 \\
Training people on separating garbage at destination & 3 & 16 & 0.05 & 0.15 \\
Existing the modern system at garbage transportation & 2 & 13 & 0.04 & 0.08 \\
Having ceiling automobile garbage transportation part & 4 & 17 & 0.05 & 0.2 \\
Thrift at primary materials & 2 & 14 & 0.03 & 0.06 \\
Decreasing a dimension and weight of garbage & 2 & 15 & 0.05 & 0.1 \\
Biotechnology development & 4 & 19 & 0.04 & 0.08 \\
\hline
\end{tabular}

\section{Table 3}

Internal factors matrix (IFE) (Opportunities)

\begin{tabular}{|c|c|c|c|c|}
\hline Strength & Current point & point & Normal & end Point \\
\hline Existing environment standards about garbage production & 4 & 20 & 0.05 & 0.2 \\
\hline Providing culture by city planning & 4 & 18 & 0.04 & 0.16 \\
\hline Regarding a time table of garbage egress & 3 & 20 & 0.05 & 0.15 \\
\hline Existing laws instruction and driving & 2 & 16 & 0.04 & 0.08 \\
\hline transportation Possibility of lorry garbage at the end time of night & 3 & 17 & 0.03 & 0.09 \\
\hline Existing the laws of environment about garbage sepulture method & 3 & 15 & 0.04 & 0.12 \\
\hline Preparing sepulture management executive schedule & 4 & 17 & 0.05 & 0.2 \\
\hline Partnership possibility of private part at garbage sepulture & 2 & 14 & 0.05 & 0.1 \\
\hline Being attractive for private part investment & 3 & 15 & 0.05 & 0.15 \\
\hline external investment attracting possibility about recycling garbage & 3 & 19 & 0.04 & 0.12 \\
\hline Existing modern technology to recycle garbage & 3 & 18 & 0.05 & 0.15 \\
\hline Threats & Current point & point & Normal & end Point \\
\hline Production dangerous garbage(hospital and electronic) increasing & 3 & 15 & 0.05 & 0.15 \\
\hline Providing culture increasing & 3 & 19 & 0.03 & 0.09 \\
\hline Existing dangerous garbage (hospital and electronic) & 4 & 18 & 0.05 & 0.2 \\
\hline Much pollution of garbage and existing vermin & 3 & 16 & 0.05 & 0.15 \\
\hline Low level of training egression of collection garbage part & 3 & 19 & 0.04 & 0.12 \\
\hline $\begin{array}{l}\text { Collection and transportation problems at raining time with regard } \\
\text { to leaking faucet from garbage }\end{array}$ & 4 & 12 & 0.05 & 0.2 \\
\hline Intercity accident possibility & 2 & 14 & 0.03 & 0.06 \\
\hline $\begin{array}{l}\text { Collection and transportation problems at raining time with regard } \\
\text { to leaking faucet from garbage }\end{array}$ & 4 & 12 & 0.05 & 0.2 \\
\hline $\begin{array}{l}\text { Being polluted natural sources especially earth and underground } \\
\text { water }\end{array}$ & 4 & 18 & 0.05 & 0.2 \\
\hline $\begin{array}{l}\text { Stability of some of garbage at environment and not attracting } \\
\text { them by environment }\end{array}$ & 2 & 15 & 0.04 & 0.08 \\
\hline Extending and speedup contagious sicknesses & 3 & 16 & 0.05 & 0.15 \\
\hline People diffidence to recycling goods & 2 & 17 & 0.03 & 0.06 \\
\hline Low standard about goods production from recycling & 2 & 13 & 0.04 & 0.08 \\
\hline Lack of workforce skillful & 3 & 15 & 0.05 & 0.15 \\
\hline Recycling technology weakness & 3 & 19 & 0.04 & 0.12 \\
\hline total & & & 1 & 0.24 \\
\hline
\end{tabular}

With regard to the estimated amount of final score in Table 2 of evaluating IFE which is equal to 2.96 units as a result with the low amount of this compared with index 3 we can say that the situation of evaluating internal factors is negative, which indicates the failure of Shiraz garbage management. Also with regard to the amount of estimated index EFE results given in Table 3, which is 3.24 since it is relatively high compared with the mean index (3), it can be concluded that external factors have been more successful than internal factors in garbage management. 
The third step: Strategies evaluation using Quantitative strategic matrix (QSPM)

In this step we try to select and prioritize effective strategies in garbage management using Quantifying Strategies Matrix and planning (QSPM) so that the attractiveness of every strategy is determined by their appropriate categorization. In order to provide Quantitative Strategies Matrix, again, IFE and EFE were given to statistical population to choose strategies. Then, based on the given scores to the aforementioned tables and tables pertaining to SWOT, the following strategies have been chosen.

S1: presenting necessary training and increasing public awareness particularly in sectors of garbage producers and those working in collection sector,

S2: garbage dividing in production place/ on the spot garbage dividing,

S3: separating dangerous hospital and electronic garbage,

S4: reconsidering Environment laws and garbage sepulture standards,

S5: appropriate location for garbage sepulture,

S6: attracting foreign investment into garbage recycling,

S7: using modern technology in garbage recycling,

S8: presenting a timetable in collecting garbage.

In terms of scores for the attractiveness, every strategy is classified into the following ranks: Score 1: without attractiveness 2: Somehow attractive 3: Reasonably attractive 4: Very attractive. In accordance with the given score by specialist and based on SWOT the strategies presented were classified in group one with very high effectiveness and priority, group 2 with high effectiveness and priority, group 3 with average effectiveness and priority, group 4 with low effectiveness and priority and group 5 with very low effectiveness and priority. Table 4 presents the quantitative evaluation of strategies.

\section{Table 4}

Matrix quantities of garbage management strategies

\begin{tabular}{|c|c|c|c|c|c|c|c|c|}
\hline Strength & ST1 & ST2 & ST3 & ST4 & ST5 & ST6 & ST7 & ST8 \\
\hline Household led man awareness & 0.2 & 0.12 & - & - & 0.2 & - & - & 0.15 \\
\hline Training collection part egression & 0.12 & 0.12 & - & - & 0.2 & - & - & 0.1 \\
\hline Advertising about a time of garbage collection & 0.2 & 0.08 & - & - & 0.12 & - & - & 0.06 \\
\hline Training producer garbage about separating garbage at destination & - & - & 0.15 & 0.2 & 0.12 & - & - & 0.08 \\
\hline Existing the modern system at garbage transportation & - & 0.12 & 0.08 & 0.1 & - & 0.12 & - & - \\
\hline Decreasing a dimension and weight of garbage & - & - & 0.2 & 0.12 & - & 0.08 & - & - \\
\hline Thrift at primary materials & - & - & 0.06 & 0.15 & - & - & - & - \\
\hline Having ceiling automobile garbage transportation part & 0.12 & 0.1 & 0.06 & 0.12 & 0.12 & 0.2 & 0.15 & 0.15 \\
\hline Total & 0.64 & 0.54 & 0.55 & 0.69 & 0.76 & 0.4 & 0.15 & 0.54 \\
\hline Strategies & ST1 & ST2 & ST3 & ST4 & ST5 & ST6 & ST7 & ST8 \\
\hline Increasing the un-renewable garbage production amount & 0.2 & - & 0.1 & 0.2 & - & 0.15 & 0.12 & - \\
\hline Providing increasing the amount of garbage at the first & 0.09 & 0.06 & 0.1 & 0.15 & 0.08 & - & - & - \\
\hline Not using unattractive materials by environment & 0.12 & 0.08 & 0.06 & - & - & - & - & - \\
\hline Increasing city traffic & 0.16 & 0.12 & - & 0.1 & 0.16 & 0.12 & 0.15 & - \\
\hline Not regarding to a garbage transportation time table & - & - & 0.12 & 0.15 & - & 0.12 & - & 0.08 \\
\hline Incorrect site selection for garbage sepulture place & - & - & - & 0.2 & 0.08 & 0.2 & - & - \\
\hline Residue unsanitary sepulture & 0.08 & 0.1 & 0.1 & - & - & 0.15 & - & - \\
\hline Garbage sepulture without considering the type of them & 0.06 & - & 0.1 & 0.15 & - & 0.2 & - & - \\
\hline Not notifying about recycling & - & 0.08 & - & 0.12 & 0.09 & 0.15 & - & 0.1 \\
\hline Opulence ability lack for recycling and separating possibility & - & - & 0.15 & 0.12 & - & - & - & - \\
\hline Low benefit of recycling garbage for garbage producer & 0.2 & 0.15 & - & 0.09 & 0.2 & - & 0.08 & - \\
\hline Not notifying about recycling & - & - & - & 0.2 & - & 0.2 & - & - \\
\hline Total & 1.11 & 0.69 & 0.93 & 1.98 & 0.81 & 1.69 & 0.47 & 0.26 \\
\hline
\end{tabular}




\begin{tabular}{|c|c|c|c|c|c|c|c|c|}
\hline Strategies & ST1 & ST2 & ST3 & ST4 & ST5 & ST6 & ST7 & ST8 \\
\hline Existing environment standards about garbage production & 0.2 & 0.16 & - & 0.12 & 0.12 & 0.15 & 0.1 & 0.16 \\
\hline Providing culture by city planning & 0.2 & 0.18 & - & 0.12 & 0.15 & 0.12 & - & 0.1 \\
\hline Regarding a time table of garbage egress & 0.2 & 0.16 & - & 0.09 & 0.12 & 0.15 & - & 0.16 \\
\hline Existing laws instruction and driving & - & - & 0.16 & 0.15 & - & 0.16 & - & - \\
\hline transportation Possibility of garbage lorry at the end time of night & 0.2 & 0.18 & - & 0.1 & 0.15 & - & 0.1 & - \\
\hline Existing the laws of environment about garbage sepulture method & 0.12 & 0.1 & 0.08 & 0.09 & 0.1 & 0.12 & 0.2 & - \\
\hline Preparing sepulture management executive schedule & 0.15 & 0.08 & 0.06 & 0.12 & 0.12 & 0.15 & - & - \\
\hline Total & 1.07 & 0.86 & 0.32 & 0.79 & 0.76 & 0.85 & 0.4 & 0.42 \\
\hline Strategies & ST1 & ST2 & ST3 & ST4 & ST5 & ST6 & ST7 & ST8 \\
\hline Production dangerous garbage(hospital and electronic) increasing & 0.15 & 0.2 & - & - & 0.1 & 0.08 & - & 0.2 \\
\hline Providing culture increasing & 0.2 & 0.2 & - & - & 0.12 & 0.1 & - & 0.2 \\
\hline Existing dangerous garbage (hospital and electronic) & 0.2 & 0.12 & - & - & 0.2 & - & - & 0.15 \\
\hline Much pollution of garbage and existing vermin & 0.16 & 0.15 & - & - & 0.16 & - & - & 0.12 \\
\hline Low level of training egression of collection garbage part & - & - & - & 0.16 & 0.1 & 0.08 & 0.2 & 0.1 \\
\hline Collection and transportation problems at raining time & - & - & 0.16 & 0.2 & 0.08 & 0.16 & - & - \\
\hline Intercity accident possibility & - & - & 0.2 & 0.15 & - & 0.08 & - & - \\
\hline $\begin{array}{l}\text { Collection and transportation problems regard to leaking faucet from } \\
\text { garbage }\end{array}$ & - & - & 0.12 & 0.1 & - & 0.1 & - & - \\
\hline Being polluted natural sources especially earth and underground water & 0.16 & 0.12 & 0.15 & 0.15 & 0.2 & 0.1 & 0.1 & 0.09 \\
\hline $\begin{array}{l}\text { Stability of some of garbage at environment and not attracting } \\
\text { them by environment }\end{array}$ & - & - & 0.12 & 0.2 & 0.1 & 0.2 & 0.04 & - \\
\hline Extending and speedup contagious sicknesses & 0.2 & 0.2 & 0.15 & 0.16 & 0.1 & 0.2 & - & 0.12 \\
\hline People diffidence to recycling goods & 0.2 & 0.2 & 0.06 & 0.04 & 0.2 & 0.1 & 0.06 & 0.15 \\
\hline Low standard about goods production from recycling & 0.12 & 0.1 & 0.16 & 0.08 & 0.1 & 0.15 & 0.2 & - \\
\hline Total & 1.39 & 0.29 & 1.12 & 1.24 & 2.18 & 1.25 & 0.6 & 1.13 \\
\hline \multirow{2}{*}{ Total points of attractive } & WS1 & WS2 & WS3 & WS4 & WS5 & WS6 & WS7 & WS8 \\
\hline & 4,21 & 3.38 & 2.92 & 3.44 & 4.51 & 4,19 & 1.62 & 2.32 \\
\hline
\end{tabular}

According to the results of Table 4, the fifth strategy (ST5) is an appropriate location for establishing recycling industries with an attractiveness score of 4.51 followed by the first strategy (ST1), training and increasing awareness in producing and collecting with an attractiveness score of 4.21, and the sixth strategy (ST6), attracting capital and participation of private sector with a score of 4.19 for Shiraz garbage management. Other strategies come as lower priorities for assigning a location for recycling system.

The fourth step: Forming the table of critical criterion and strategy appointing.

In this step, after a comprehensive investigation on the capacities and capabilities based on SWOT model, capacities and capabilities are classified and every capability or capacity with the highest score of the mean / average [critical criterion] will be selected as the intervention strategy. Table 5 shows details of the implementation of this step. As we can observe the mean of the attractiveness of garbage management strategies is calculated as 3.044.

\section{Table 5}

Critical criterion of capabilities and capacities according to table QSPM

\begin{tabular}{lllll}
\hline & Capability and capacity & $\begin{array}{l}\text { Sum of total } \\
\text { point }\end{array}$ & $\begin{array}{l}\text { Point } \\
\text { average }\end{array}$ & $\begin{array}{l}\text { Difference } \\
\text { every point }\end{array}$ \\
\hline 1 & Training and awareness increasing at collection and production & 4.21 & 3.33 & 0.88 \\
\hline 2 & Garbage separating in production place & 3.38 & 3.33 & 0.05 \\
\hline 3 & Separating dangerous hospital and electronic garbage & 2.92 & 3.33 & -0.41 \\
\hline 4 & Retrospection at environment laws and garbage sepulture & 3.44 & 3.33 & 0.11 \\
\hline 5 & Correct site selection for garbage sepulture place & 4.51 & 3.33 & 1.18 \\
\hline 6 & Attracting external investment at recycling garbage & 4.19 & 3.33 & 0.86 \\
\hline 7 & Using the end technology at garbage recycling & 1.62 & 3.33 & -1.71 \\
\hline 8 & Time table presentation about garbage collection & 2.35 & 3.33 & -0.98 \\
\hline
\end{tabular}




\section{Conclusion}

In this paper, we have presented an empirical study to find strength, weakness, opportunities and threats against a waste management unit located in city of Shiraz located in south west of Iran. We have asked some experts to assign points to each criteria and based on the scores determined the relative position of each factor influencing the criteria. Based on the results, appropriated locating strategies for burying garbage, training and increasing awareness regarding production and collection, attracting foreign investment in the field of recycling garbage, reconsidering environmental rules and burying garbage and its separation standards are the most important strategies.

\section{References}

Clarke, K.C., \& Gaydos, L. (1998). Loose coupling a cellular automation model and GIS: Long-term growth prediction for San Francisco and Washington/Baltimore. International Journal of Geographical Information Science, 12(7), 699-714.

Chang, N.B., Shoemaker, C.A., \& Schuler, R.E. (1996). Solid waste management systems analysis with air pollution and leachate impact limitations. Waste Management \& Research, 14(5), 463481.

David, F.R. (1998). Strategic Management: Concepts and Cases. Prentice-Hall, New Jersey, 88-91.

Eastman, R., Jin, W., Kyem, P.A.K., \& Toledano, J. (1995). Photogrammetric Engineering \& Remote Sensing, 61(5), 539-547.

Engelen, G., White, R., \& Uljee, I. (1997). Integrating constrained cellular automata models, GIS and decision support tools for urban planning and policy-making, Decision support systems in urban planning, E \& FN Spon, London, UK.

Halla, F. (2007). A SWOT analysis of strategic urban development planning: The case of Dares Salaam city in Tanzania. Habitat International, 31, 130-142.

Johnson, G., Shcoles, K., \& Sexty, R.W. (1989). Exploring strategic management. Scarborough, Prentice-Hall, Ontario, 345.

Kurttila, M., Pesonen, M., Kangas, J., \& Kajanus, M. (2000). Utilizing the analytic hierarchy process (AHP) in SWOT analysis - a hybrid method and its application to a forest-certification case. Forest Policy and Economics, 1(1), 41-52.

Kumar, S., Mondal, A.N., Gaikwad, S.A., Devotta1, S., \& Singh, R.N. (2004). Qualitative assessment of methane emission inventory from municipal solid waste disposal sites: a case study. Atmospheric Environment, 38(29), 4921-4929.

Scarlett, L. (2007). A consumer's guide to environmental myths and realities. National center for Policy Analysis, Executive Summary, Policy Report No. 165.

Stewart, R.A., Mohamed, S., \& Daet, R. (2002). Strategic implementation of IT/IS a project in construction: A case study. Automation in Construction, 11, 681-694.

Tammemagi, H. (1999). The Waste Crisis: Landfills, Incinerators, and the Search for a Sustainable Future. Oxford University Press, New York, USA, 32-36.

Williams, P.T. (1998). Waste treatment and disposal. John Wiley \& Sons, UK. 